\title{
State of emergency medicine in Spain
}

\author{
Òscar Miró
}

Received: 28 April 2010 /Accepted: 11 October 2010 /Published online: 8 December 2010

(C) The Author(s) 2010. This article is published with open access at Springerlink.com

\begin{abstract}
Spain has universal public health care coverage. Emergency care provisions are offered to patients in different modalities and levels according to the characteristics of the medical complaint: at primary care centers (PCC), in an extrahospital setting by emergency medical services (EMS) and at hospital emergency departments (ED). We have more than 3,000 PCCs, which are run by family doctors (general practitioners) and pediatricians. On average, there is 1 PCC for every 15,000 to 20,000 inhabitants, and every family doctor is in charge of 1,500 to 2,000 citizens, although less populated zones tend to have lower ratios. Doctors spend part of their duty time in providing emergency care to their own patients. While not fully devoted to emergency medicine (EM) practice, they do manage minor emergencies. However, Spanish EMSs contribute hugely to guarantee population coverage in all situations. These EMS are run by EM technicians (EMT), nurses and doctors, who usually work exclusively in the emergency arena. EDs dealt with more than 25 million consultations in 2008, which implies, on average, that one out of two Spaniards visited an ED during this time. They are usually equipped with a wide range of diagnostic tools, most including ultrasonography and computerized tomography scans. The
\end{abstract}

The views expressed in this paper are those of the author(s) and not those of the editors, editorial board or publisher.

\section{Ò. Miró $(\bowtie)$}

Emergency Department, Hospital Clinic,

Villarroel 170,

08036 Barcelona, Catalonia, Spain

e-mail: omiro@clinic.ub.es academic and training background of doctors working in the ED varies: nearly half lack any structured specialty residence training, but many have done specific master or postgraduate studies within the EM field. The demand for emergency care has grown at an annual rate of over $4 \%$ during the last decade. This percentage, which was greater than the $2 \%$ population increase during the same period, has outpaced the growth in ED capacity. Therefore, Spanish EDs become overcrowded when the system exerts minimal stress. Despite the high EM caseload and the potential severity of the conditions, training in EM is still unregulated in Spain. However, in April 2009 the Spanish Minister of Health announced the imminent approval of an EM specialty, allowing the first EM resident to officially start in 2011. Spanish emergency physicians look forward to the final approval, which will complete the modernization of emergency health care provision in Spain.

Keywords Emergency medicine $\cdot$ Research $\cdot$ Teaching . Specialty $\cdot$ Resident

\section{Introduction}

Spain, 1 of the 27 countries constituting the European Union, is located in the southwest of Europe. It had an area of $505,988 \mathrm{~km}^{2}$ with a population of $46,157,822$ inhabitants as of 2008. At that time, the International Monetary Fund placed Spain 9th worldwide in nominal gross domestic product (GDP) and 25th according to its per capita GDP [1]. Spain is politically and administratively divided into 17 autonomous communities, which are partially ruled by democratically elected regional governments: 15 are located 
on the Iberian Peninsula, and 2 are archipelagos (the Canary Islands located in the Atlantic Ocean, off the northwest coast of Africa, and the Balearic Islands located in the Mediterranean Sea). These autonomous communities are heterogeneous in terms of extension and population, ranging from more than 8 million people in Andalusia to 0.3 million in La Rioja (Fig. 1). The largest cities in Spain are Madrid (3.2 million), Barcelona (1.6 million), Valencia (0.8 million) and Seville (0.7 million) [2]. Additionally, Spain receives nearly 60 million tourists every year, with some areas increasing their population several fold during the summer [3].

\section{Health care provision}

Spain has universal public health care coverage, which is recognized and warranted by its Constitution and provided by the Spanish government. Although it was designed to be supported economically by mixed revenue from employer and employee contributions and from the general national budget through taxes, the latter now provides the vast majority of funding [4]. For the last 25 years, every Spanish autonomous community has progressively taken full responsibility for the organization of the health care provision to their citizens according to their own local particularities, while at the same time fulfilling generic rules imposed by the Spanish Ministry of Health. This process was completed in 2002. This system has pros and cons: while it involves some fragmentation of health care provision, it allows greater proximity to local geographic and demographic needs. Today every Spanish citizen has his/her individual health care card provided by the local authorities, which entitles him/her to seek and receive health care assistance throughout the country. In general, the majority of services are free, although the card owner must contribute to some extent (which varies according to age and other particular circumstances) to drug costs, optic and hearing devices, some dental care and a few other services. The Spanish citizens can also obtain the European Health Insurance Card (EHIC) that provides, with a few variations among countries, free non-scheduled health care assistance within the European Union. Additionally, Spaniards may also receive free health care if they are traveling outside the European Union, provided that the country in question has a reciprocal health care arrangement with Spain.

In addition, approximately $20 \%$ of Spanish citizens also have private medical insurance [5]. This insurance varies according to the coverage paid for by the consumer. As a general rule, the insurance company covers the health care costs, but insured individuals have no right to economic

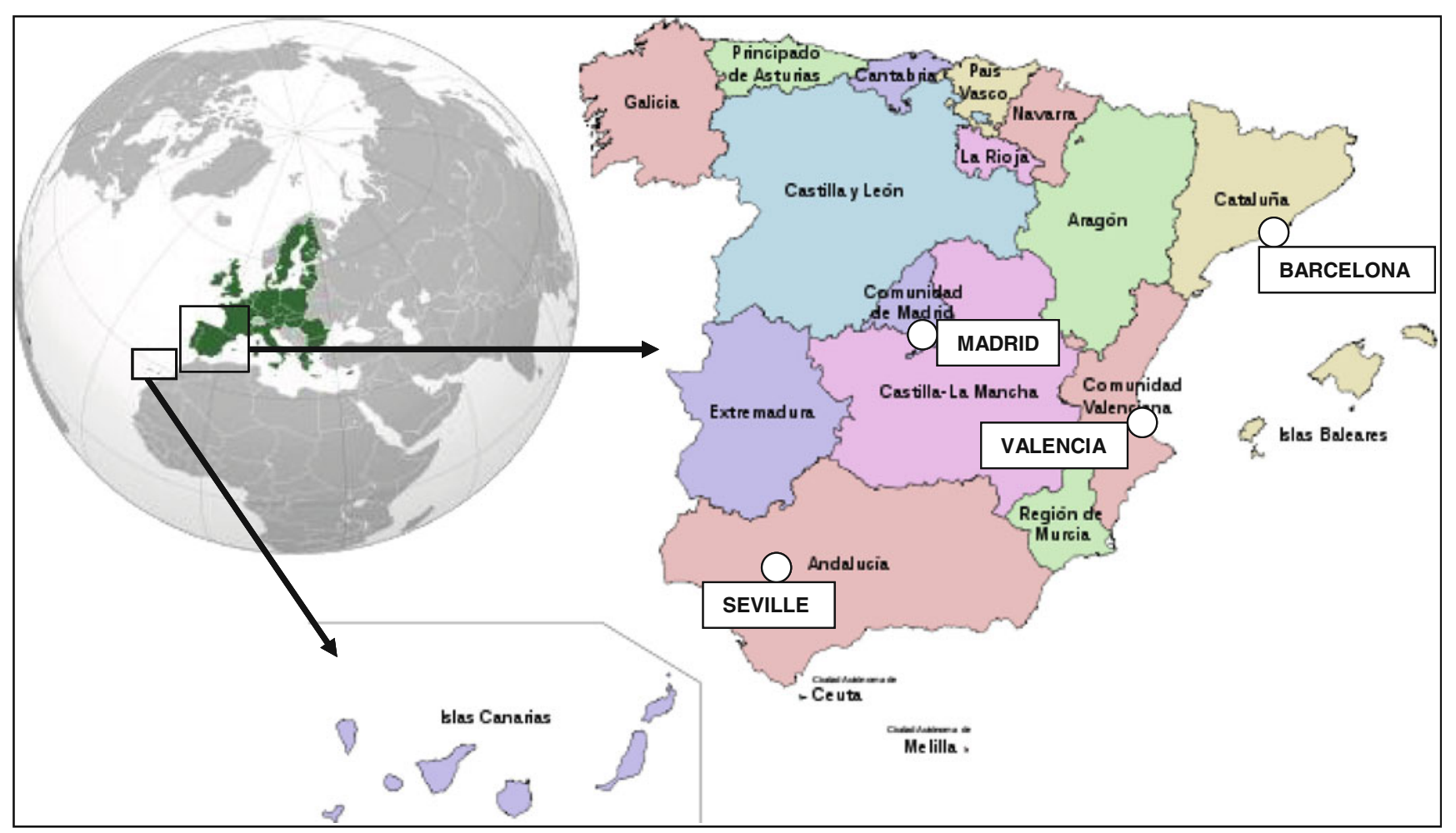

Fig. 1 Map of Spain 
compensation for illness. Accordingly, there are some private centers (ranging from small private medical clinics to large high-tech hospitals) that exclusively work with these individuals. However, some of these centers may provide health care services to both public (health care card holders) and private (private insurance or direct patient payment) consumers.

The official sanitary and health data published in 2003 [6] are as follows: 78.7 years of life expectancy at birth; perinatal and infantile mortality rates under 5 per 1,000 alive newborns; cardiovascular diseases as the main (34.9\%) cause of death; road accident death rate of 1.4 per 10,000 inhabitants per year; and working death rate of 4.8 per 100 million worked hours.

\section{Emergency care provision}

The emergency care provision is offered to patients in different modalities and levels according to the characteristics of the medical complaint. Classically, it is divided into three different parts based on the three main sources of emergency care: emergency consultations attended at primary care centers (PCC); in a community setting by emergency medical services (EMS); and at hospital emergency departments (ED). The resources and resolution capacity of each level are clearly different. From the human resources point of view, since the EM specialty for doctors and nurses does not yet exist in Spain, their professional profile varies widely, especially depending on the type of work center where they are employed.

For all the above-mentioned reasons, policy makers and administrators request that the population use all these free resources in accordance with their level of need. ED should be reserved for more complex patients to avoid overcrowding; however, it is well accepted that internal factors (i.e., those depending on the system) play a more important role than external factors (i.e., demand pressure) in explaining the generalized delays in receiving urgent care. Among the former factors, the lack of hospital beds to admit boarding ED patients, as well as patients waiting for outcome after initial assessment and treatment, are the most important causative agents for ED collapse [7, 8]. Accordingly, policies have been repeatedly addressed to increase the coordination among these three levels of emergency care provision [9-12].

Emergency care provided by primary care centers

Spain has more than 3,000 PCCs, which are run by family doctors (general practitioners) and pediatricians. Some PCCs also include other specialties such as gynecology and orthopedic surgery. On average, there is 1 PCC for every 15,000 to 20,000 inhabitants, and every family doctor is in charge of 1,500 to 2,000 citizens, although less populated zones tend to have lower ratios. Doctors spend part of their duty time in providing emergency care to their own patients. They are not fully devoted to EM practice, but sufficiently manage minor emergencies. Patients with a non-scheduled urgent consultation can usually obtain an appointment within 24-72 $\mathrm{h}$ with their own doctor; otherwise, they can be visited the same day by another doctor from the center. Patients with mobility problems may be visited at home during the day by their general practitioner. In general, complementary immediate tests available in PCC are limited and usually consist of electrocardiography and blood and urine sticks.

During the past few years, effort has been made to provide more powerful diagnostic tools at this level. Today radiographies, dry biochemistry, blood analysis and pulse-oxymetry are provided in selected PCCs, with a specific location where emergency consultations are attended $24 \mathrm{~h}$ a day. Some PCCs are even equipped with small observation units to maintain patients up to 6-12 $\mathrm{h}$ if home discharge is anticipated. Doctors working in these new PCC emergency facilities are, in most cases, fully devoted to EM: in many cases they are not the PCC family doctors; rather, many are hired exclusively as emergency physicians (EP) to provide attention to these emergency consultations. Another important change in the concept of medical care has entailed moving from the primary care continuous attention concept towards a continuous emergency attention model. These new emergency centers are only partially available in the largest cities. Their effectiveness will help the administration to decide if this policy should be maintained or even expanded [13].

Emergency care provided by emergency medical systems

Spanish EMSs contribute hugely to guarantee population coverage in all situations. They are run by EM technicians (EMT), nurses and doctors who usually work exclusively in the emergency arena. Their role in big cities is essential, often providing continuous at-home services during PCC off-hours. Characteristically, the demand is greater on weekends and between 3-10 pm, probably influenced by PCC time tables. Respiratory problems are the main complaint treated by EMS $[14,15]$. Despite concerns of EMS overuse due to their easy access, prompt response, at-home care delivery and zero cost to the consumer, it has been repeatedly demonstrated that EMSs in Spain are not used as a first option to enter the health care system [14-16].

Public spaces are a major scenario for EMS for both minor emergencies and accidents, as well as mass casualties and catastrophes [17]. Spanish EMSs have faced major catastrophes in recent years, with the Madrid bombing 
terrorist attacks on 11 March 2004 being the largest. Extensive analysis and description of such actions have been published abroad [17-20]. In this setting, the provision of health care with advanced cardiac life support (ACLS) units is crucial. Very recently, the distribution of ACLS units has been published [21]: in January 2009, Spain had 362 operative teams (327 corresponding to road transport ambulances and 35 to helicopter ambulances) operating at a ratio of 1 ACLS unit to 127,308 inhabitants (0.78/100,000 population) with ratios varying four-fold among different geographic areas. In addition, EMS can provide support for patient transportation in isolated areas from low- to high-tech hospitals. A recent study showed that, although exclusive internal hospital resources were used in $58.3 \%$ of transportations, $33.3 \%$ required a combination of their own services and outside suppliers provided by EMSs, and the EMSs were exclusively used by $8.3 \%$ of the hospitals [22]. Emergency medical service provided by helicopters, which include trained physicians and nurses in their crews, merits special mention because they ensure correct medical care and transfer from isolated geographic zones, especially in the archipelagos [22-25]. Finally, coordination of medical care from EMSs is carried out in centralized centers where experienced doctors, nurses and technicians assign the best resource according to wellstructured, computerized protocols.

\section{Emergency care provided by hospital emergency} departments

EDs dealt with more than 25 million consultations in 2008, which implies, on average, that one out of two Spaniards visited an ED during this time. They are usually equipped with a wide range of diagnostic tools, most including ultrasonography and computerized tomography scans. Today the academic and training background of doctors working in the ED varies, although most work well in all types of emergencies because of full-time dedication to EM. Nearly half lack any structured specialty residency training, but many of them have done specific master or postgraduate studies within EM.

At the end of the 1990s Spanish EDs had some deficiencies, which were investigated and reported by Montero et al. in a series of papers [26-28] evaluating nearly 200 Spanish EDs. The most relevant deficiencies were the following: heterogeneous hierarchic assignation of the ED within the hospital with less than one-half being considered a true department; the insufficient number of rooms in $40 \%$ of EDs, mainly in those located in the highest level hospitals; and the lack of complementary exploration/analysis facilities assigned exclusively to the ED in most centers. Additionally, they found a large proportion of the patients coming to the ED spontaneously, avoiding the remaining emergency extrahospital points of care. They also reported an excessive health care burden per ED at high-tech hospitals, while the community EDs were those proportionally worse off in human (physician) resources. Finally, they detected a non-adequate form of work, which for staff was usually 8-h shifts and night duties, supported by intern and resident physicians, mainly in their first or second year of training.

Since then, some efforts have been made to correct these ED deficiencies. An increasing number of EDs have achieved the status of independent hospital departments, their patient capacity has been raised, different strategies to re-direct patient flows have been approached and substantial increases in the number of ED staff have been made. Additionally, the work schedule is shifting in most Spanish EDs from a mixed model of 8 -h shifts plus 24-h duties to a model exclusively based on 8-h or a maximum of 12-h shifts to match the European directives regarding work days [29]. However, these changes in work hours will need some additional years to be fully implemented in all EDs of the public health care system.

Unfortunately, all these changes have not been enough. The demand for emergency care at EDs has been growing at an annual rate of over $4 \%$ during the last decade, double the $2 \%$ population increase (mainly due to immigration [30]) registered during that period and surpassing the growth in hospital ED capacity [31]. Therefore, EDs become overcrowded when the system exerts minimal stress [32-34], which has a clear impact on the quality of care provided [35]. It is, however, a seemingly unavoidable effect in all developed countries providing free universal health care and ED access [36]. This situation has prompted all the personnel involved to make changes to ameliorate this condition [37]. In an attempt to decrease ED arrivals, a partial payment for services has been proposed in some situations, especially when misused [38], as has patient diversion to other system resources [39], or an offer to call services for better guidance to thereby avoid a part of hospital ED consultations [40]. The rationale for such actions is based on the fact that in Spain, as in most other countries, around $30 \%$ of ED consultations are identified as inadequate demand, using objective tools of measurement [41-43]. On the other hand, greater efforts have been made to adapt the physical structure and human resources to cope with this increasing demand [44]. One of the most remarkable initiatives has been the implementation of triage systems for prioritizing patient assistance based on the severity of their condition [45]. Spain has no common triage model. The Manchester, Canadian and Spanish systems are used widely across the country; the latter [Sistema Español de Triage (SET) or Spanish Triage 
System)] was specifically designed, developed and recommended by the Spanish Society of Emergency Medicine (SEMES) [46]. Most EDs have redesigned their circuits and patient flow to gain efficiency [47], although most of the benefits of these changes have shown to dissipate within only a few years [48]. In some instances, depending on the ED staff, specific observation and/or short-stay units have been launched $[49,50]$. When measured, this model has proved to be more efficient than other classical management models [51-54]. Another example of coordination among different emergency levels of actuation is the installation, in many big Spanish cities, of activation codes for certain pathologies (like acute myocardial infarction, stroke, polytrauma, sepsis), which have allowed improvement in quality and results [55].

\section{The Spanish Society for Emergency Medicine (SEMES)}

The efforts previously discussed imply the participation of around 50,000 professionals across the country, including doctors, nurses and EMTs. The main scientific society that joins all these professionals is the SEMES. Founded in 1988, it has 7,587 members, including 5,366 doctors, 1,236 nurses and 985 EMTs. In a recent paper [56], its three past presidents reviewed the main goals achieved during the organization's 20 years of existence: the development and consolidation of several courses for continuous learning of professionals; the publication of hundreds of books and manuals; the definition of accreditation criteria for PCCs attending emergencies, EMSs and EDs; the foundation of EMERGENCIAS, the SEMES scientific journal published since 1988 and currently edited bimonthly; the participation in all forums where EM is involved and/or debated; the organization of an annual meeting in early June that includes around 2,000 attendees [57], as well as several regional meetings; joining the European Society of Emergency Medicine (EuSEM); the creation of its own accreditation model for EM doctors, nurses and EMT based on both curriculum merits and a specific annual exam; and the recent achievement of official academic recognition and regulation of EMT by the Spanish authorities.

However, the main point lacking is the recognition of the medical and nursing specialties in EM. Regarding the first, it seems we are nearly there. In April 2009, the Spanish Minister of Health, Bernat Soria, announced the imminent approval of the EM specialty, allowing the first EM residency to start in 2011 [58]. This promise was confirmed and assumed by his substitute, Trinidad Jiménez, in a public interview a few days after joining the Ministry [59]. Therefore, after the consolidation of EDs in the majority of hospitals and the adjustment of staff requirements, the SEMES looks forward to final approval of the EM specialty, which should be achieved during the next few months and will complete the modernization of emergency health care provision in Spain.

In the meantime, accreditation for doctors and nurses promoted and developed by SEMES remains the only structured certification of adequate knowledge and skills in emergency medicine. They are obtained by an annual national exam and, although not officially recognized by health or education authorities, they retain a high level of prestige among Spanish emergency physicians and nurses.

\section{Emergency medicine in Spanish medical schools}

Despite the high caseload in EM and the potential severity of conditions attended, training in EM is still unregulated in Spain. With respect to medical school teaching of EM, Coll-Vinent and coworkers have very recently reviewed the medical school programs at Spanish universities [60]: 22 of the 28 Spanish medical school programs have at least one subject specifically focusing on EM, although in most cases this subject is an elective that only lasts 4 months. The number of credits and the scope and content of the syllabi vary considerably, as do the methods of assessing student performance. In general, EM courses do not follow SEMES recommendations. Accordingly, academic EM departments are essentially lacking since the professors teaching EM courses come from departments such as anesthesia and internal medicine, and provide instruction in a nonstandardized fashion. This issue should be addressed in the near future.

\section{EM specialty development}

The formation of medical specialists in Spain is regulated by a 1984 law [61], and it has been developed through a competitive national residency program since 1989 [62]. Today this program oversees 48 different medical specialties. Despite SEMES efforts to include EM as one of these specialties, this has not yet occurred. From conversations between the SEMES and the Spanish health authorities, it seems that the creation of the EM specialty will be linked to a fully redesigned residency program, which transforms the residency system from 48 individual specialty programs working independently to a few branches joining specialties with common program parts, where uniform training will be given during the first years of residency. Thereafter, specific specialty training will be completed during the last years. First drafts have placed EM in the same branch as 
family medicine and internal medicine, with 2 years of common training and 3 additional years of specialized training in EM. These drafts were proposed by the SEMES [63] and other scientific societies as well as by the "Pre" Council of Emergency Medicine [64] (created by the Ministry of Health); however, they are still pending approval by the Minister of Health. This is in accordance with the EM curriculum launched by the EuSEM [65] and recently approved by the UEMS (European Union of Medical Specialists), which has been fully subscribed to by the SEMES. Meanwhile, EM is being developed for doctors coming from family medicine, internal medicine, pediatrics and intensive care specialties; in some cases these doctors will dedicate their professional lives to EM practice. A mechanism for the recognition of such doctors as specialists in EM is also anticipated with the proposal that they be recognized as EM specialists made by the government coinciding with the approval of EM as a primary specialty. Both launching EM residency and recognition of current EM physicians are still waiting to be published as a Royal Decree [66].

\section{Research in emergency medicine}

The research activity from 1975 to 2004 produced 606 papers (20.2 per year) authored by Spanish EPs in indexed journals: two-thirds written in Spanish, $50 \%$ original research and most from EPs working at hospitals. Research showed a great dispersion, since 137 centers yielded at least one paper, although the majority came from Catalonia, Andalusia and Madrid. The average impact factor was 1.11, with an index of no citation of $45 \%$, and indexes of inhospital, out-hospital and international collaborative studies of $57 \%, 19 \%$ and $4 \%$, respectively. All these indexes were lower than those observed for the whole Spanish scientific production, although they showed a significant improvement over the last 30 years [67]. However, the production volume of Spanish EPs ranks among the lowest among other medical specialties in Spain (hematology, endocrinology, cardiology, respiratory, gastroenterology, pediatrics, surgery and trauma) and those of EPs abroad (USA, UK, Ireland, Italy, France, Germany, The Netherlands and Belgium). By contrast, the ratio of productivity of Spanish EPs over the last 10 years has shown the greatest increase among all the Spanish medical specialties examined and ranks only second among that of EPs abroad, being only surpassed by that of specialists from The Netherlands [68]. These results have been achieved regardless of the fact that papers published by Spanish EPs in indexed journals only account for half of their overall work, with the remaining articles published in EMERGENCIAS, the scientific journal of SEMES, which is currently not indexed $[69,70]$. This is additional proof that the EM specialty in Spain is a reality despite the lack of official approval.

Acknowledgements -Òscar Miró has received an Intensification Research Grant from Instituto de Salud Carlos III (Spanish Health Ministry) for 2009.

Thanks are due to the Hospital Clinic of Barcelona for a 6-month grant to gain insight into development of the EM specialty outside of Spain.

This work was partially supported by a grant from the Generalitat de Catalunya (SGR 2009-1385).

Thanks are due to Drs. T,. Toranzo, G. Burillo and M. J. VázquezLima for their thoughtful comments and criticisms on a previous version of this manuscript, and to Dr. J. Casey for copy editing of the final version.

\section{Conflicts of interest None.}

Open Access This article is distributed under the terms of the Creative Commons Attribution Noncommercial License which permits any noncommercial use, distribution, and reproduction in any medium, provided the original author(s) and source are credited.

\section{References}

1. International Monetary Fund (Accessed 07/09/2009) Available from: http://www.imf.org/external/index.htm

2. Instituto Nacional de Estadística (Accessed 07/09/2009) Available from: http://www.ine.es/

3. Instituto de Estudios Turísticos. Balance del Turismo: informe 2008. (accedido 28/10/2009). Available from: http://www.iet. tourspain.es/informes/documentacion/FronturFamilitur/Balance\% 20del $\% 20$ turismo $\% 20$ en $\% 20$ Espana $\% 20$ en $\% 202008$.pdf

4. Ley General de Sanidad 14/1986 (accessed 26/10/2009) Available from: http://www.msc.es/organizacion/sns/docs/financiacion08.pdf

5. Gonzalez BY, Urbanos RM (2004) Oferta pública y privada de servicios sanitarios por comunidades autónomas. Gac Sanit 18 (suppl1):82-89

6. Ministerio de Sanidad y Consumo. Datos básicos de la salud y los servicios sanitarios en España. (accessed 15/10/2009). Available from: http://www.msc.es/estadEstudios/estadisticas/docs/Datos basicos_salud.pdf

7. Miró O, Sánchez M, Coll-Vinent B et al (2000) Estimación del efecto relativo que ejercen los determinantes externos e internos sobre la eficacia de un servicio de urgencias de medicina. Med Clin (Barc) 115:294-296

8. Espinosa G, Miró O, Sánchez M, Coll-Vinent B, Millá J (2002) Effects of external and internal factors on emergency department overcrowding. Ann Emerg Med 39:693-695

9. Montero Pérez FJ (2007) La organización de la cadena asistencial urgente en España o la búsqueda de los eslabones perdidos. Emergencias 20:5-7

10. García Bermejo P, Mínguez Platero J, Ruiz López JL, Millán Soria J, Trescoli Serrano C, Tarazona Ginés E (2008) Gestión integral del área de urgencias y coordinación con atención primaria. Emergencias 20:8-14

11. Jiménez S, de la Red G, Miró O, Bragulat E, Coll-Vinent B, Senar E et al (2005) Efectividad de la incorporación de un médico especialista en medicina familiar y comunitaria en un servicio de urgencias hospitalario. Med Clin (Barc) 125:132-137

12. Sánchez M (2004) ¿Urgencias inadecuadas u oferta insuficiente? Med Clin (Barc) 123:619-620 
13. Urbano P. SEMES: los CUAP son buenos dispositivos extrahospitalarios. (accessed: 15/10/2009). Available from: http:// dccu.forogratis.es/board/semes-los-cuap-son-buenos-dispositivosextrahospitalarios-t2546.html\#

14. Ortega Maján MT, Rabanaque Hernández MJ, Júdez Legaristi D, Cano Del Pozo MI, Abad Díez JM, Moliner Lahoz J (2008) Perfil de los usuarios y motivos de demanda del Servicio de Urgencias extrahospitalario 061. Emergencias 20:27-34

15. del Pozo MI Cano, Rabanaque Hernández MJ, Feja Solana C, Martos Jiménez MC, Abad Díez JM, Celorrio Pascual JM (2008) Estudio de la frecuentación de un servicio de urgencias extrahospitalario. Emergencias 20:179-186

16. Pérez-Ciordia I, Guillén Grima F (2009) Urgencias hospitalarias y extrahospitalarias en Navarra. Razones que las motivan. An Sist Sanit Nav 32:371-384

17. Corral E (2009) Atentados del 11-M en Madrid: reflexiones 5 años después. Emergencias 21:141-142

18. Carresi AL (2008) The 2004 Madrid train bombings: an analysis of pre-hospital management. Disasters 32:41-65

19. Miquel Gómez A, Domínguez Jiménez C, Pedrueza Ibarguren C, Ruiz R, Lillo Martín V, Canas Mayol J (2007) Management and analysis of out-of-hospital health-related responses to simultaneous railway explosions in Madrid, Spain. Eur J Emerg Med 14:247-255

20. Jiménez Murillo L, Casado Martínez JL, Burillo Putze G (2004) Emergency medicine in Spain. Eur J Emerg Med 11:185-186

21. Pesqueira Alonso EE, Juliani Izquierdo P (2009) Unidades de soporte vital avanzado en España 2008. Mapa de situación. Emergencias 21:276-282

22. Vázquez Lima MJ, Álvarez Rodríguez C (2008) Transporte interhospitalario urgente desde los hospitales comarcales. Emergencias 20:245-250

23. Burillo-Putze G, Duarte IH, Alvarez Fernandez JA (2001) Helicopter emergency medical service in Spain. Air Med J 20:21-23

24. Jiménez Murillo L, Casado Martínez JL, Burillo Putze G (2004) Emergency medicine in Spain. Eur J Emerg Med 11:185-186

25. Lubillo S, Burillo-Putze G, Alonso E, Herranz I, Gomez A, Gomez N (2000) Helicopter emergency medical service in Canary Islands, Spain. Eur J Emerg Med 7:55-59

26. Montero Pérez FJ, Calderón de la Barca Márquez JM, Jiménez Murillo L, Berlango Jiménez A, Pérula de Torres L (2000) Situación actual de los Servicios de Urgencias Hospitalarios en España (I): Descripción general y análisis de la estructura física y funcional. Emergencias 12:226-236

27. Montero Pérez FJ, Calderón de la Barca Márquez JM, Jiménez Murillo L, Berlango Jiménez A, Pérez Torres I, Pérula de Torres L (2000) Situación actual de los Servicios de Urgencias Hospitalarios en España (II): Actividad asistencial, docente e investigadora. Emergencias 12:237-247

28. Montero Pérez FJ, Calderón de la Barca Márquez JM, Jiménez Murillo L, Berlango Jiménez A, Pérez Torres I, Pérula de Torres L (2000) 248 Situación actual de los Servicios de Urgencias Hospitalarios en España (III): Recursos materiales y humanos. Perfil profesional del médico de Urgencias. Emergencias 12:248258

29. Directiva 2003/88/CE del Parlamento europeo y del Consejo. Diario oficial de la Unión Europea. 18-11-2003. (Accessed 15-102009). Available from: http://www.fetyc.cgt.es/IMG/pdf/Dir 2003.88.CE_ord._algunos_aspectos_del_to_de_trabajo.pdf

30. Junyent $M^{-}$, Miró $\mathrm{O}$, Sánchez $\mathrm{M}^{-}(2006) \overline{-}$ Comparación de la utilización de los servicios de urgencias hospitalarios entre la población inmigrante y la población autóctona. Emergencias 18:232-235

31. Zaragoza Fernández M, Calvo Fernández C, Saad Saad T, Morán Portero FJ, Sanjosé Pizarro S, Hernández Arenillas P (2009) Evolución de la frecuentación en un servicio de urgencias hospitalario. Emergencias 21:339-345
32. Sánchez M, Miró O, Coll-Vinent B et al (2003) Saturación del servicio de urgencias: factores asociados y cuantificación. Med Clin (Barc) 121:167-172

33. Sánchez M, Salgado E, Miró O (2008) Mecanismos organizativos de adaptación y supervivencia de los servicios de urgencia. Emergencias 20:48-53

34. Espinosa G, Miró O, Coll-Vinent B, Sánchez M, Millá J (2002) Effects of internal and external factors on emergency department overcrowding. Ann Emerg Med 39:693-695

35. Miró O, Sánchez M, Coll-Vinent B, Millá J (2001) Indicadores de calidad en urgencias: comportamiento en relación con la presión asistencial. Med Clin (Barc) 116:92-97

36. Richardson DB, Mountain D (2009) Myths versus facts in emergency department overcrowding and hospital access block. Med J Aust 190:369-374

37. Miró O (2009) El usuario y su uso de las urgencias. An Sist Sanit Nav 32:311-316

38. Moreno Millán E (2007) Ventajas e inconvenientes del copago en la financiación y gestión de la atención sanitaria urgente. Emergencias 19:32-35

39. Miró O, Salgado E, Tomás S et al (2006) Derivación sin vista desde los servicios de urgencias hospitalarios: cuantificación, riesgos y grado de satisfacción. Med Clin (Barc) 126:88-93

40. Coma E, De la Haba I, Comabella R, Zayas S, Armisen A, Ciurana R et al (2009) La atención telefónica urgente especializada: una manera de mejora en la utilización de los servicios de urgencias hospitalarios. Emergencias 21:117-120

41. Aranaz JM, Martínez R, Rodrigo V et al (2004) Adecuación de la demanda de atención sanitaria en servicios de urgencias hospitalarios. Med Clin (Barc) 123:615-618

42. Sempere-Selva T, Peiró S, Sendra P, Martínez C, López I (2001) Inappropriate use of an accident and emergency department: magnitude, associated factors and reasons- an approach with explicit criteria. Ann Emerg Med 37:568-579

43. Oterino D, Peiró S, Calvo R, Sutil P, Fernández O, Pérez G, Torre P, López M, Sempere T (1999) Accident and emergency department inappropriate utilization. An evaluation with explicit criteria. Gac Sanit 13:361-370

44. Moreno Millán E (2008) ¿Y si adaptáramos los servicios hospitalarios de urgencias a la demanda social y no a las necesidades de salud? Emergencias 20:276-284

45. Martín-Sánchez FJ, González-Del Castillo J, Zamorano J, Candel FJ, González-Armengol JJ, Villarroel P et al (2008) El facultativo, un elemento necesario en el triaje de un Servicio de Urgencias en un hospital terciario. Emergencias 20:41-47

46. Gómez Jiménez J, Torres Trillo M, López Pérez J, Jiménez Murillo L (2004) Sistema Español de Triaje (SET). Sociedad Española de Medicina de Urgencias y Emergencias (SEMES), Madrid

47. Miró O, Sánchez M, Espinosa G, Coll-Vinent B, Bragulat E, Milla $\mathrm{J}$ (2003) Analysis of patient flow in the emergency department and the effect of an extensive reorganisation. Emerg Med J 20:143-148

48. Miró O, Salgado E, Sánchez M (2009) Why are strategies for improving ED effectiveness so volatile? J Emerg Med. in press

49. Aldea-Molina E, Gómez J, Royo R, Rodrigo G, Rivas M, Llera R (2008) Sala de observación de un servicio de urgencias: un lugar adecuado para el manejo del flutter auricular. Emergencias 20:101-107

50. González-Armengol JJ, Fernández Alonso C, Martín-Sánchez FJ, González-Del Castillo J, López-Farré A, Elvira C et al (2009) Actividad de una unidad de corta estancia en urgencias de un hospital terciario: cuatro años de experiencia. Emergencias 21:8794

51. Juan A, Salazar A, Alvarez A, Perez JR, Garcia L, Corbella X (2006) Effectiveness and safety of an emergency department 
short-stay unit as an alternative to standard inpatient hospitalisation. Emerg Med J 23:833-837

52. Salazar A, Juan A, Ballbe R, Corbella X (2007) Emergency shortstay unit as an effective alternative to in-hospital admission for acute chronic obstructive pulmonary disease exacerbation. Am J Emerg Med 25:486-487

53. Salazar A, Estrada C, Porta R, Lolo M, Tomas S, Alvarez M (2009) Home hospitalization unit: an alternative to standard inpatient hospitalization from the emergency department. Eur J Emerg Med 16:121-123

54. Salazar A (2009) ¿Urgenciólogos rentables? Emergencias 21:83-84

55. Gómez-Angelats E, Bragulat E, Obach V, Gómez-Choco M, Sánchez M, Miró O (2009) Resultados alcanzados con la puesta en marcha del circuito "Código Ictus" en un gran hospital: papel de urgencias y análisis de la curva de aprendizaje. Emergencias 21:105-113

56. Moreno Millán E, Millá Santos J, Jiménez Murillo L (2008) Congresos de la Sociedad Española de Medicina de Urgencias y Emergencias (I): recuerdos y reflexiones de 20 años de actividad institucional. Emergencias 20:353-358

57. Casal Codesido JR, García-Castrillo Riesgo L, Miró O (2008) Congresos de la Sociedad Española de Medicina de Urgencias y Emergencias (y II): evolución de 20 años de actividad científica. Emergencias 20:428-434

58. Sanidad anuncia nuevas especialidades: Psiquiatría InfantoJuvenil y Urgencias. (Accessed 19-10-2009). Available from: http://www.larazon.es/noticia/sanidad-anuncia-nuevas-especiali dades-psiquiatria-infanto-juvenil-y-urgencias

59. Entrevista a Trinidad Jiménez. Ministra de Sanidad y Política Social. (Accessed: 15/10/2009). Available: http://www.telemadrid. es/contenidos/html/elcirculo/pagina_trinidadjimenez19.htm

60. Coll-Vinent B, Sánchez M, Nogué Bou R, Miró O (2009) La enseñanza de la Medicina de Urgencias y Emergencias en las facultades de medicina: situación actual. Emergencias. in press

61. Real Decreto $127 / 1984$, de 11 de Enero, por el que se regula la formación médica especializada y la obtención del título de Médico Especialista. Boletín Oficial del Estado, Madrid, 31-011984

62. Orden de 27 de Junio de 1989, por la que se establecen las normas reguladoras de las pruebas selectivas para el acceso a plazas de Formación Sanitaria Especializada. Boletín Oficial del Estado, Madrid, 28-06-1989

63. Proyecto formativo troncal de la Especialidad de Medicina de Urgencias y Emergencias. Accesed 03-07-2009. Available from: http://www.scribd.com/doc/4081436/Proyecto-Troncal-de-laEspecialidad-de-Medicina-de-Urgencias-y-Emergencias

64. Comisión promotora de la especialidad de urgencias y emergencias. Subdirección general de ordenación profesional. Ministerio de Sanidad y Consumo. Propuesta de Programa formativo Troncal de las Especialidades de: Medicina Familiar y Comunitaria. Medicina Interna. Medicina de Urgencias y Emergencias. (accessed 15-102009). Available from: www.semes.org

65. EuSEM Task Force European Core Curriculum for the EM speciality training in Europe (Spanish translation). Emergencias 2009; $21: 456-470$

66. Sociedad Española de Medicina de Urgencias y Emergencias. Borrador de proyecto de real decreto por el que se crea el titulo de médico especialista en urgencias y emergencias. Accessed 15-10-2009. Available from: http://www.semes.org/images/ stories/pdf/PROYECTO\%20RD\%20URGENCIAS\%20Y\% 20EMERGENCIAS.pdf

67. Miró O, Salgado E, González-Duque A, Tomás S, Burillo-Putze G, Sánchez M (2007) Producción científica de los urgenciólogos españoles durante los últimos 30 años (1975-2004). Análisis bibliométrico descriptivo. Emergencias. 19:6-15

68. Miró O, Salgado E, González-Duque A, Tomás S, BurilloPutze G, Sánchez M (2007) Producción científica de los urgenciólogos españoles durante los últimos 30 años (19752004). Análisis comparativo con la actividad de otras especialidades en España y con la de urgenciólogos de otros países. Emergencias 19:59-64

69. Miró O, González-Duque A, Cinesi C, Tomás S, Pacheco A, Sánchez M et al (2008) Artículos publicados en EMERGENCIAS entre 2000 y 2004: participación de los urgenciólogos y comparación con su aportación en las revistas indexadas. Emergencias 20:308-315

70. Andreu AL (2008) La medicina de urgencias en el contexto de la $\mathrm{I}+\mathrm{D}+\mathrm{i}$ en España. Emergencias 20:297-298

Òscar Miró is 45 and has been working as an emergency physician at the Hospital Clinic in Barcelona since completing his medical training in Internal Medicine in 1995. This hospital, which is one of four tertiary care teaching hospitals in Barcelona city, has an assigned population of about 500,000 inhabitants. Its ED annual census nowadays reaches more than 125,000 visits. Regarding his postgraduate education, Dr. Miró received his $\mathrm{PhD}$ in 1999 and completed a Master in Hospital Administration in 2002. Since 1995, he has also been greatly interested in research, publishing nearly 200 scientific articles. Mainly, his efforts have focused on two fields: mitochondrial disturbances (obviously a little far away from ED topics) and strategies to study and face ED overcrowding. Over the last 3 years, he has participated as a scientific secretary on the board of the Catalonian Emergency Medicine Society. Finally, since 2007, he has been the editor-in-chief of EMERGENCIAS, the Spanish Scientific Journal on Emergency Medicine, which is owned by SEMES (the Spanish Society for Emergency Medicine). 